\title{
PENGEMBANGAN MODUL PROTOTIPE BAHAN AJAR CETAK MATA KULIAH PENDIDIKAN LINGKUNGAN HIDUP PADA PENDIDIKAN TERBUKA DAN JARAK JAUH: STUDI KASUS DI UNIVERSITAS TERBUKA
}

\section{DEVELOPMENT OF PRINTED TEACHING MATERIALS PROTOTYPE MODULE OF ENVIRONMENTAL EDUCATION COURSE IN OPEN AND DISTANCE EDUCATION: A CASE STUDY IN OPEN UNIVERSITY}

\author{
Maman Rumanta, Krisna Iryani, Anna Ratnaningsih \\ FKIP-Universitas Terbuka \\ e-mail: mamanr@ecampus.ut.ac.id atau maman0563@gmail.com
}

Naskah diterima tanggal: 18/1/2016, Direvisi akhir tanggal: 15/8/2016, disetujui tanggal: 29/8/2016

\begin{abstract}
The purpose of this research is to produce the module prototype of teaching material on the Environmental Education course in Open University. This research used the formative evaluation technique, by developing, a prototype of module of teaching material on Human Being, Energy, and Natural Resource as a model in writing other modules. The module was tested and revised gradually, starting from one-to-one evaluation; the small group evaluation; and field evaluation. The result of the research shows that several deficiencies were found in the module prototype on the one-to-one evaluation, such as the less obvious picture with the description written in foreign language, formative test that is not suitable with the material, and some terms that are not clearly explained. The result of small group evaluation also shows that the material on module prototype is too excessive and there are some topics that must be revised. Meanwhile, the result of field test shows that the module prototype is quite good and it can be understood by respondents, but there are still suggestions related to the use of term that is not obvious. It can be concluded that the prototype of teaching material for Environmental Education is quite good to use as the teaching material for distance education after evaluation, revision, and field test, with a little bit the revision especially related to the use of term.
\end{abstract}

Keywords: prototype module development, printed teaching material, environmental education course, distance learning module

\begin{abstract}
Abstrak: Penelitian ini bertujuan untuk mendapatkan prototipe modul pada bahan ajar mata kuliah Pendidikan Lingkungan Hidup, Universitas Terbuka. Penelitian ini menggunakan teknik evaluasi formatif, dengan mengembangkan satu prototipe modul bahan ajar berupa modul 2 tentang Manusia, Energi, dan Sumber Daya Alam, sebagai model dalam penulisan modul lainnya. Prototipe modul bahan ajar tersebut diuji coba dan direvisi secara bertahap, mulai dari evaluasi satu-satu dilanjutkan dengan evaluasi kelompok kecil, dan evaluasi lapangan. Hasil penelitian menunjukkan bahwa pada evaluasi satu-satu, ditemukan adanya beberapa kekurangan, seperti gambar yang kurang jelas dengan keterangan masih menggunakan bahasa asing, tes formatif yang tidak sesuai dengan materi, serta beberapa istilah yang belum dijelaskan. Hasil evaluasi kelompok kecil menunjukkan materi pada prototipe modul bahan ajar tersebut terlalu banyak, kualitas gambar kurang memadai, dan ada beberapa materi yang perlu diperbaiki. Sedangkan hasil uji lapangan menunjukkan bahwa prototipe modul tersebut sudah cukup baik dan dapat dimengerti responden, namun masih ada saran penggunaan istilah yang belum jelas. Disimpulkan bahwa setelah melakukan serangkaian evaluasi dan revisi diakhiri dengan uji lapangan, prototipe modul bahan ajar Pendidikan Lingkungan Hidup tersebut cukup baik untuk digunakan sebagai bahan ajar pendidikan jarak jauh, dengan beberapa catatan perbaikan khususnya penggunaan istilah.
\end{abstract}


Kata kunci: pengembangan modul prototype, bahan ajar cetak, pendidikan lingkungan hidup, pendidikan jarak jauh

\section{PENDAHULUAN}

Bahan ajar cetak merupakan bagian yang sangat penting dalam pembelajaran pada pendidikan tinggi jarak jauh seperti Universitas Terbuka. Pengembangan bahan ajar cetak Universitas Terbuka telah dilakukan menurut prosedur standar ISO 9001-2008. Prosedur diawali dengan penyusunan oleh penulis bahan ajar; penelaahan oleh seorang ahli materi yang memberikan masukan terhadap draf tersebut; penelaahan oleh pengampu mata kuliah mengenai kebahasaan dan desain instruksionalnya. Dalam penulisan bahan ajar Universitas Terbuka, para penulis dan perevisi bahan ajar dibekali dengan rancangan mata kuliah (RMK) yang terdiri dari analisis instruksional (AI) dan garis besar program pembelajaran (GBPP), serta laporan evaluasi bahan ajar.

Berdasarkan prosedur pengembangan naskah bahan ajar cetak tersebut nampak bahwa pengembangan bahan ajar Universitas Terbuka sudah cukup baik, namun belum menggunakan standar penelitian dan pengembangan (research and development). Revisi bahan ajar belum mengacu pada standar evaluasi formatif secara utuh. Hal ini terjadi dalam penulisan buku apa pun di Indonesia, bahkan hal serupa terjadi pula di Amerika Serikat. Dick, Carey \& Carey (2009) mengungkapkan bahwa menurut hasil penelitian, ribuan produk pembelajaran yang dijual setiap tahunnya di Amerika Serikat belum dievaluasi oleh pebelajar (learner) dan direvisi sebelum didistribusikan. Padahal beberapa peneliti telah membuktikan bahwa pengembangan bahan ajar atau program pembelajaran melalui penelitian pengembangan dan evaluasi formatif menghasilkan bahan ajar atau program pembelajaran yang efektif (Suwiwa dkk., 2014; Sukerni, 2014; Arlitasari dkk.,2013; Ediyanto, 2014; Suartama, 2010).

Bertolak dari uraian di atas, sudah saatnya Universitas Terbuka mempertimbangkan kebijakan baru berkenaan dengan pengembangan maupun revisi bahan ajar. Hal ini bukan berarti bahwa bahan ajar yang dihasilkan saat ini tidak berkualitas, namun akan lebih baik lagi jika proses pembuatan bahan ajar ini mengacu pada pembuatan bahan ajar yang memadai, melalui research and development $(R \& D)$ dan evaluasi (formatif dan sumatif).

Bila pola pembuatan bahan ajar tersebut dijadikan kebijakan baru, kualitas bahan ajar Universitas Terbuka di masa yang akan datang dapat diperkirakan akan semakin meningkat. Hal ini dimungkinkan karena evaluasi bahan ajar dapat digunakan sebagai alat untuk mengambil kebijakan, seperti diungkapkan oleh Dunn \& Mulvenon (2009) "Evaluasi formatif juga menginformasikan kebijakan, yang dapat mempengaruhi evaluasi praktek, guru, dan siswa di masa yang akan datang".

Dalam rangka pembenahan bahan ajar tersebut, dilakukan evaluasi formatif terhadap bahan ajar mata kuliah Pendidikan Lingkungan Hidup (PLH). Pemilihan mata kuliah tersebut didasari oleh kenyataan bahwa bahan ajar tersebut digunakan oleh mahasiswa yang jumlahnya cukup banyak yaitu mahasiswa S1 Pendidikan Guru Sekolah Dasar (PGSD) dan S1 Pendidikan Biologi. Mata kuliah tersebut banyak dikeluhkan oleh mahasiswa, khususnya mahasiswa PGSD karena banyak memperoleh nilai kurang baik, bahkan banyak yang gagal (mendapat nilai E). Hasil analisis butir soal mata kuliah Pendidikan Lingkungan Hidup pada 3 masa ujian (2010.1, 2011.1, dan 2011.2) menunjukkan bahwa rata-rata soal yang diujikan 50\%-nya perlu direvisi, padahal kalau ditelaah lebih lanjut, soal tersebut sebagian besar masih cukup baik. Hal ini menunjukkan banyaknya mahasiswa yang kurang paham materi bahan ajar yang diujikan, sehingga daya beda soal menjadi kurang berfungsi. Karena itulah mata kuliah ini menarik untuk dikaji melalui evaluasi formatif dengan mengembangkan prototipe modul bahan ajar. Dalam penelitian ini prototipe 
modul bahan ajar yang dimaksud adalah Modul 2 mata kuliah Pendidikan Lingkungan Hidup, yaitu tentang Manusia, Energi dan Sumber Daya Alam.

Berdasarkan latar belakang, rumusan permasalahan adalah sebagai berikut. 1) Bagaimana tanggapan dan saran responden terhadap prototipe modul bahan ajar PLH pada evaluasi satu-satu? 2) Bagaimana tanggapan dan saran responden terhadap prototipe modul bahan ajar PLH pada evaluasi kelompok kecil? 3) Apakah prototipe modul bahan ajar PLH yang telah direvisi berdasarkan masukan dari hasil evaluasi kelompok kecil layak dijadikan prototipe modul bahan ajar jarak jauh yang memenuhi harapan pengguna di lapangan?

Berdasarkan rumusan masalah tersebut, maka tujuan penelitian ini adalah untuk mengetahui: 1) tanggapan dan saran dari responden terhadap prototipe modul bahan ajar PLH pada evaluasi satu-satu, 2) tangggapan dan saran dari responden terhadap prototipe modul bahan ajar PLH pada evaluasi kelompok kecil, 3) apakah prototipe modul bahan ajar yang telah direvisi berdasarkan masukan dari hasil evaluasi kelompok kecil layak dijadikan prototipe modul yang memenuhi harapan pengguna di lapangan.

\section{KAJIAN LITERATUR}

\section{Pengembangan Bahan Ajar pada Institusi Pendidikan Jarak Jauh}

Pendidikan jarak jauh (PJJ) merupakan salah satu model pembelajaran yang kini berkembang pesat seiring dengan kemajuan di bidang iptek. Ciri PJJ, antara lain adanya keterpisahan ruang dan waktu antara pengajar dan peserta didik, sehingga proses pembelajaran yang digunakan menekankan pada proses belajar mandiri, menggunakan berbagai media yang memungkinkan terjadinya pertukaran data, informasi, dan pengetahuan (Suparman, 2014). Oleh karena itu, dalam pengembangannya, bahan ajar cetak pendidikan jarak jauh, didesain dengan menggunakan struktur yang sangat ketat dan memuat informasi yang sangat padat (Pribadi \& Syarif, 2010). Hal ini dikarenakan bahan ajar tersebut akan berperan sebagai pengganti pengajar bagi peserta didiknya.

Sebagai institusi PJJ, Universitas Terbuka telah mengembangkan prosedur pengembangan bahan ajar, baik bahan ajar cetak maupun non cetak, seiring dengan penerapan ISO 9001-2008 di Universitas Terbuka. Prosedur pengembangan bahan ajar cetak harus melalui beberapa tahapan berikut. Pertama, bahan ajar disusun oleh penulis yang ahli di bidangnya. Setelah tersusun, draf bahan ajar tersebut ditelaah oleh seorang ahli materi lain, yang bertugas memberikan masukan terhadap draf tersebut. Selanjutnya draf yang telah diperbaiki berdasarkan hasil telaah materi tersebut ditelaah oleh pengampu dari segi kebahasaan dan desain instruksional.

Dari proses penulisan dan pengembangan tersebut, diperoleh bahan ajar mandiri yang cukup berkualitas, karena telah mengadaptasi model desain instruksional yang dikembangkan Dick \& Carey (Suparman, 2014). Dalam proses pengembangan bahan ajar Universitas Terbuka saat ini, tampaknya masih perlu disempurnakan karena belum memenuhi proses pengembangan bahan ajar yang utuh dan berkelanjutan. Tahapan yang belum terstruktur dan seringkali dilewati adalah tahap evaluasi formatif, yang belum dijalankan secara berkesinambungan. Evaluasi formatif merupakan tahapan yang sangat penting dalam pengembangan bahan ajar. Dick, Carey \& Carey (2009) mengungkapkan bahwa uji coba terhadap bahan ajar yang dilakukan kepada satu orang pebelajarpun untuk kemudian direvisi menunjukkan perbedaan yang signifikan terhadap efektivitas bahan ajar. Sedangkan evaluasi formatif pada intinya melakukan serial uji coba dan revisi yang dilakukan terhadap draf bahan ajar yang baru dikembangkan, sehingga diperoleh bahan ajar yang valid dan efektif.

\section{Evaluasi Formatif}

Evaluasi formatif merupakan salah satu tahapan dalam model desain instrusional yang dikembangkan Dick, Carey \& Carey (2001). Keller 
(1987) mengungkapkan bahwa dalam proses pengembangan bahan ajar, dimulai dengan penyusunan draf bahan ajar, direviu oleh pakar dan calon pembaca, untuk mendapatkan umpan balik dalam proses penyempurnaan (revisi). Hal yang sama diungkapkan oleh Dick, Carey \& Carey (2009) bahwa hasil evaluasi formatif dapat digunakan untuk meningkatkan kualitas bahan ajar cetak (BAC) pada saat revisi.

Bahan ajar yang beredar di lapangan akan dibaca oleh pembaca (pebelajar). Jika dalam bahan ajar tersebut terdapat kesalahan, maka kesalahan tersebut akan menyebabkan pebelajar mendapat pemahaman yang salah. Apakah bahan ajar tersebut mudah dipahami? Apakah bahan ajar tersebut menyenangkan?, dan seterusnya. Dengan evaluasi formatif, kelemahan-kelemahan bahan ajar tersebut akan terungkap dan dapat segera direvisi.

Dalam prosedur evaluasi formatif masih terdapat beberapa perbedaan, namun pada prinsipnya melalui beberapa tahapan. Diungkapkan oleh Dick Carey \& Carey (2001) dan Tessmer (1993, dalam Ogle, 2002) bahwa meskipun masih ada sedikit variasi, evaluasi formatif meliputi tahapan-tahapan utama berikut: reviu pakar, evaluasi satu-satu, evaluasi kelompok kecil, dan uji lapangan.

Pertama, reviu pakar. Reviu pakar merupakan tahap awal evaluasi formatif. Reviu pakar menurut Ogle (2002) merupakan suatu evaluasi intrinsik bahan ajar yang berfokus pada akurasi konten atau kualitas teknis bahan ajar tersebut. Dalam kegiatan reviu pakar dapat dilaksanakan oleh beberapa orang ahli misalnya ahli materi, ahli desain instruksional dan ahli media. Hasil reviu pakar dijadikan masukan guna perbaikan bahan ajar yang sedang dikembangkan. Kedua, evaluasi satu-satu. Evaluasi satu-satu merupakan evaluasi bahan ajar setelah melalui revisi dengan mengakomodasi masukan pakar. Evaluasi ini bertujuan untuk mengidentifikasi dan mengurangi kesalahan dalam bahan ajar dan mendapat komentar mengenai isi bahan ajar tersebut oleh pebelajar. Evaluasi satu-satu dilaksanakan antara pengembang desain instruksional dengan beberapa orang pebelajar secara individual. Dalam penentuan sampel pebelajar sebagai subjek penelitian harus representatif, yaitu mewakili kelompok pebelajar kurang pandai, rata-rata, dan pandai. Hasil evaluasi satu-satu dijadikan masukan dalam revisi bahan ajar yang sedang dikembangkan. Ketiga, evaluasi kelompok kecil. Evaluasi kelompok kecil merupakan tahap lanjut dari evaluasi bahan ajar setelah direvisi berdasarkan hasil evaluasi satu-satu, yang melibatkan sekitar 8-20 orang siswa. Sama halnya dengan evaluasi satu-satu, evaluasi kelompok kecil juga harus terdiri dari sampel yang representatif terhadap populasi di mana bahan instruksional nantinya akan dipakai. Hasil evaluasi kelompok kecil juga digunakan untuk revisi bahan ajar yang sedang dikembangkan. Keempat, Uji Coba Lapangan. Uji coba lapangan bertujuan untuk mengidentifikasi kekurangan produk instruksional jika dipergunakan dalam kondisi lingkungan yang mirip dengan kondisi lingkungan sebenarnya di mana produk tersebut akan dimanfaatkan. Dalam kegiatan ini diperlukan sampel pebelajar sebanyak 15-30 orang.

\section{Kelebihan Evaluasi Formatif}

Evaluasi formatif diperlukan untuk mengetahui apakah suatu bahan ajar perlu direvisi atau tidak. Dengan demikian, suatu bahan ajar yang telah melewati proses evaluasi formatif akan lebih berkualitas, karena melalui evaluasi formatif itulah efektivitas dan efisiensi bahan ajar ditingkatkan (Triantafillou dkk., 2003). Sedangkan hasil penelitian Hattie dkk. (2006) membuktikan bahwa evaluasi formatif secara signifikan dapat meningkatkan inovasi dalam teknologi pendidikan. Oleh karena itu, melalui evaluasi formatif akan dihasilkan bahan ajar yang sesuai harapan para pembacanya (pebelajar). Selain itu, bahan ajar yang telah melalui evaluasi formatif akan lebih terpercaya dari segi konten, akurasi, kedalaman materi, kemutakhiran, desain, dan cara penyajiannya karena telah melalui revisi berdasarkan masukan oleh para pakar materi dan desain instruksional. 
Maman Rumanta, Krisna Iryani, Anna Ratnaningsih, Pengembangan Modul Prototipe Bahan Ajar Cetak Mata Kuliah Pendidikan Lingkungan Hidup pada Pendidikan Terbuka dan Jarak Jauh

Hasil evaluasi formatif diharapkan dapat memberikan masukan bagi kegiatan revisi bahan ajar, baik dari segi substansi materi atau desain instruksional (Yuliana dkk., 2012).

\section{Kelemahan Evaluasi Formatif}

Evaluasi formatif merupakan prosedur yang sangat dihargai dalam dunia ilmiah untuk mendapatkan bahan ajar atau program pembelajaran yang baik. Namun, evaluasi ini masih banyak kendala dalam pelaksanaannya, karena ada beberapa kelemahan yang membuat orang enggan melakukannya. Flagg (1990) mengidentifikasi 6 alasan mengapa orang resisten terhadap evaluasi formatif, yaitu: 1) Waktu. Dalam hal deadline waktu suatu proyek sangat mendesak, maka pengembang cenderung tidak melakukan evaluasi formatif guna menghemat waktu; 2) Biaya. Kebanyakan pengembangan bahan ajar tidak memiliki cukup dana untuk melakukan evaluasi formatif; 3) Sifat dasar manusia. kebanyakan pengembang bahan ajar merasa kurang nyaman, jika hasil karyanya dikritisi oleh pengguna dan pakar lain. Pengembang sering menganggap kritik pengguna sebagai kurang paham dan kritik pakar lain sebagai ancaman; 4) Harapan yang realistik. Meskipun evaluasi formatif menghasilkan informasi untuk memandu pengambilan suatu keputusan, namun evaluasi formatif tersebut tidak dapat menggantikan keahlian dan kreativitas pengembang berkualitas; 5) Kesulitan pengukuran. Meskipun beberapa aspek evaluasi formatif mudah diukur, namun masih terdapat keterbatasan metode yang dapat diandalkan, valid, dan layak untuk mengevaluasi beberapa jenis hasil pembelajaran interaktif; dan 6) Terbatasnya pengetahuan. Ahli evaluasi formatif belum banyak tersedia dalam industri pengembangan sistem pembelajaran interaktif atau pun dalam akademisi. Banyak pengembang bahan ajar tidak memiliki kemampuan untuk melakukan evaluasi formatif secara sistematik.

Dengan demikian jelaslah mengapa tidak banyak para pengembang bahan ajar yang melakukan evaluasi formatif. Keenam hal tersebut menjadi kendala dalam pelaksanaan evaluasi formatif. Selain itu, kesabaran dan ketekunan peneliti sangat dituntut dalam pelaksanaan evaluasi formatif. Oleh karena itu, para pakar pendidikan seringkali mengurangi langkah-langkah yang dilakukan oleh Dick and Carey tersebut, menjadi tiga bahkan dua langkah saja.

Beberapa peneliti telah melakukan prosedur evaluasi formatif bukan hanya terhadap pengembangan bahan ajar cetak, melainkan dalam pengembangan bahan ajar online, bahkan dalam pengembangan kurikulum. Stewart dkk. (2004) melakukan evaluasi formatif dan sumatif untuk mengetahui persepsi pebelajar terhadap pembelajaran online (online courses), sehingga kekuatan dan kelemahan program tersebut diketahui dan dapat diperbaiki. Yoshida (2010) yang melakukan penelitian tentang "development and formative evaluation of the educational media in service curriculum standards"; Jha \& Duffy (2002) dengan judul "ten golden rules for designing software in medical education": results from a formative evaluation dialog". Semua penelitian formatif tersebut bertujuan untuk mengevaluasi dan memperbaiki bahan ajar atau program pembelajaran.

\section{METODE}

Penelitian ini merupakan penelitian lanjutan dari evaluasi formatif setelah prototipe modul bahan ajar direvisi berdasarkan hasil reviu pakar. Subjek penelitian pada penelitian ini adalah mahasiswa Program Pendidikan Dasar UPBJJUniversitas Terbuka Serang-Banten, kelompok belajar (Pokjar) Tangerang, yang belum menempuh mata kuliah Pendidikan Lingkungan Hidup. Pengambilan sampel responden dilakukan dengan teknik purposive sampling, dengan pertimbangan responden adalah mahasiswa yang belum mengambil mata kuliah Pendidikan Lingkungan Hidup serta pertimbangan dari segi efisiensi dan efektivitas pengambilan data.

Pada tahap ini, penelitian difokuskan pada evaluasi satu-satu hingga uji coba lapangan. Evaluasi satu-satu (one-to-one evaluation). 
Evaluasi ini bertujuan untuk mengidentifikasi dan mengurangi kesalahan dalam bahan ajar dan mendapat komentar mengenai isi bahan ajar tersebut dari mahasiswa. Responden dalam tahap ini adalah 3 orang, mahasiswa S1 PGSD yang mewakili kelompok kurang pintar, sedang, dan pintar yang belum mengambil mata kuliah Pendidikan Lingkungan Hidup. Langkah-langkah evaluasi ini adalah sebagai berikut: a) Mengumpulkan responden di suatu ruangan dan menjelaskan maksud dari evaluasi ini kepada mereka; b) Mengajak responden membaca bahan ajar tersebut secara bersama-sama dan mendis-kusikan kekurangan atau kelemahan yang masih ada. Peneliti mendorong mahasiswa untuk memberikan komentar secara bebas dengan cara melingkari setiap materi yang dirasa masih kurang baik dan mengomentarinya; c) Memberikan angket berupa skala penilaian terhadap bahan ajar yang dipelajarinya, dan diakhiri dengan tes lisan untuk mengetahui sejauh mana responden menguasai materi bahan ajar tersebut. Data yang diperoleh dari hasil evaluasi satu-satu dianalisis dan hasilnya dijadikan masukan untuk revisi tahap I terhadap prototipe yang dikembangkan.

Evaluasi kelompok kecil (small group evaluation). Tujuan utama dari tahap ini adalah untuk mengetahui efektivitas dari hasil revisi tahap I terhadap prototipe modul bahan ajar yang sedang dikembangkan dan mengidentifikasi kemungkinan masalah yang masih dijumpai oleh mahasiswa. Responden dalam evaluasi ini sebanyak 9 orang mahasiswa yang juga mewakili kelompok kurang pintar, sedang, dan pintar. Pengambilan data dimulai dengan cara responden diberi pre-test, mempelajari prototipe modul bahan ajar, kemudian diberi post-test. Wawancara dilakukan untuk mengetahui lebih lanjut atas masukan yang mereka berikan. Data terkumpul dianalisis dan hasilnya digunakan sebagai bahan untuk melakukan revisi tahap II terhadap prototipe modul bahan ajar yang sedang dikembangkan.

Uji coba lapangan. Responden pada tahap ini adalah 15 orang yang juga mewakili kelompok kurang pintar, sedang, dan pintar. Data dikumpulkan dengan cara sebagai berikut: a) Responden sebanyak 15 orang dalam satu ruangan dan dijelaskan apa yang akan dilakukan. (b) Mereka diberi pre-test, kemudian mempelajari bahan ajar dan diakhiri dengan posttest. (c) Wawancara dilakukan untuk menggali lebih jauh keterangan yang diperlukan dari responden. Data yang diperoleh dianalisis secara deskriptif kualitatif sebagai bahan masukan untuk revisi akhir prototipe modul bahan ajar yang sedang dikembangkan.

\section{Analisis Data}

Hasil penelitian ini diolah dengan teknik analisis deskriptif untuk data kualitatif dan teknik analisis statistik inferensial untuk data kuantitatif. Secara rinci, teknik analisis data yang digunakan adalah sebagai berikut.

\section{Teknik Analisis Data Kualitatif}

Teknik analisis ini digunakan untuk menentukan ketepatan, keefektivan, dan kemenarikan prototipe modul bahan ajar yang dikembangkan. Ada dua jenis data kualitatif yaitu: 1) Data kualitatif murni yang berupa data deskriptif, hasil komentar dan wawancara terbuka dengan mahasiswa yang dijadikan responden; 2) Data kualitatif yang dapat dikuantifikasi, yaitu data yang diperoleh dari angket/check list. Data kualitatif murni dianalisis secara deskripsi, yaitu dengan cara mengelompokkan data sejenis, mereduksi data terkumpul, dan menyimpulkannya. Sedangkan data kualitatif yang dikuantifikasi dianalisis dengan menggunakan teknik statistik deskriptif menggunakan perangkat lunak SPSS versi 20.

\section{Teknik Analisis Data Kuantitatif}

Data kuantitatif dalam penelitian ini berupa hasil pre-test dan post-test mahasiswa yang dijadikan subjek penelitian. Untuk mengetahui ada tidaknya perbedaan antara pre-test dan post-test dilakukan dengan uji beda menggunakan uji t dependent sample test. Syarat dari uji t adalah data yang akan diuji harus memenuhi 
unsur normalitas distribusi dan homogenitas variansi. Jika salah satu atau kedua kelompok data tersebut tidak berdistribusi normal, maka uji beda dilakukan dengan menggunakan uji non parametrik (uji Wilcoxon). Jika hasil uji normalitas menunjukkan bahwa kedua kelompok data tersebut berdistribusi normal, tetapi variansinya tidak homogen, maka digunakan uji t. Jika data tersebut berdistribusi normal dan variansinya homogen, maka uji beda tersebut dilakukan dengan uji t. Semua analisis data ini menggunakan perangkat lunak SPSS versi 20 .

\section{HASIL DAN PEMBAHASAN Evaluasi Satu-satu}

Berdasarkan instrumen penilaian bahan ajar dari tiga responden, secara umum dapat dijelaskan bahwa prototipe modul bahan ajar telah memenuhi kriteria kejelasan, dampak, dan kelayakan materi maupun waktu yang dibutuhkan. Namun, terdapat beberapa gambar yang keterangannya perlu diganti menggunakan bahasa Indonesia. Seperti diungkapkan oleh dua responden saat diwawancara sebagai berikut. Responden pertama mengungkapkan bahwa: "Secara keseluruhan materi modul ini mudah dipahami, bahasa dan kalimatnya mudah dimengerti, kegunaannya bagi guru khususnya guru Sekolah Dasar cukup memadai. Selain itu contoh dan ilustrasi yang disajikan cukup membantu pemahaman materi yang disajikan. Dari segi kelayakan waktu, sangat cukup dapat dipahami jika dipelajari selama 15 jam. Namun ada beberapa yang harus diperbaiki, yaitu masih ada pengetikan yang salah. Ada istilah yang kurang konsisten, misalnya istilah diperbaharui atau terbaharui dan ada pertanyaan dalam tes formatif 3 yang tidak ada dalam uraian materi.

Hal tersebut menunjukkan bahwa selain kelebihan yang ada, ternyata masih diperlukan beberapa perbaikan untuk meningkatkan kualitas prototipe modul yang sedang dikembangkan. Hal serupa juga dikemukakan oleh responden lainnya yang mengungkapkan bahwa: "Pada umumnya modul ini sudah cukup baik, baik dari kejelasan uraian materi, contoh, gambar/ ilustrasi dan bahasanya yang mudah dimengerti. Dari segi kegunaannya cukup membantu guru dan dapat dimengerti secara baik dalam waktu kurang dari 15 jam. Namun demikian, ada beberapa hal yang perlu diperbaiki diantaranya konsistensi penggunaan istilah (misalnya: diperbaharui atau diperbarui?). Keterangan gambar menggunakan kalimat asing, sebaiknya diterjemahkan atau dijelaskan secara detail dan ada soal tes formatif yang kurang sesuai dengan tujuan.

Hasil reviu langsung oleh responden pada modul juga menggambarkan hal yang sama, yaitu: 1) penggunaan istilah-istilah dengan bahasa asing perlu diperjelas, 2) gambar pada umumnya kurang jelas dan masih menggunakan bahasa asing, perlu diterjemahkan atau dijelaskan, dan 3) terdapat tes formatif yang materinya tidak ada dalam isi modul. Hal ini menunjukkan bahwa penggunaan bahasa dan istilah dalam prototipe modul bahan ajar ini masih perlu diperbaiki. Bahasa yang digunakan dalam pengembangan bahan ajar sangat menentukan keberhasilan pembaca atau siswa dalam memahami materi ajar. Suswina (2011) mengungkapkan bahwa, "Dalam mengembangkan bahan ajar, penggunaan bahasa menjadi salah satu faktor yang penting. Bahasa yang digunakan juga harus komunikatif (Pangesti, 2012). Hal senada diungkapkan Yuliana, dkk. (2012) bahwa penggunaan bahasa yang interaktif dan komunikatif, dengan perwajahan yang menarik, diharapkan materi bahan ajar dapat dipahami dengan baik oleh pebelajar. Selain penggunaan bahasa yang masih lemah prinsip konsistensi dalam pengembangan bahan belum sepenuhnya terpenuhi, di mana masih terdapat materi tes fortmatif yang tidak sesuai dengan uraian materi bahan ajar.

\section{Evaluasi Kelompok Kecil}

\section{Penilaian Responden Terhadap Prototipe} Secara Umum

Hasil penelitian menunjukkan bahwa penilaian responden terhadap prototipe modul bahan ajar yang dikembangkan, secara umum dapat dilihat 
pada Gambar 1. Secara umum responden menilai baik terhadap prototipe modul bahan ajar yang sedang dikembangkan. Berdasarkan data responden diketahui bahwa materi dalam modul bahan ajar menarik untuk dipelajari dan mudah dipahami. Namun, terdapat $14 \%$ responden yang menyatakan beberapa bagian pada bahan ajar sulit dipahami. Pembahasan materi dianggap masih kurang jelas.

\section{Penilaian Responden terhadap Uraian Materi dan Ilustrasi}

Hasil analisis instrumen tentang kejelasan materi dan ilustrasi yang ditampilkan, menunjukkan bahwa sebagian besar responden menilai cukup baik. Untuk lebih jelasnya dapat dilihat pada
Gambar 2, bahwa sebagian besar responden memandang uraian materi dan ilustrasi prototipe modul bahan ajar cukup baik. Materi mudah dipahami, dengan ilustrasi yang dapat membantu menambah penguasaan materi. Uraian materi dalam bahan ajar cukup menarik, namun ada $28 \%$ responden yang menyatakan uraian tersebut terlalu banyak dan membosankan. Ilustrasi cukup memadai dari segi jumlah dan kualitas, namun terdapat $28 \%$ responden yang tidak setuju dengan pernyataan tersebut. Mereka menganggap sebagian gambar kurang jelas, dan masih ada yang menggunakan keterangan gambar dalam bahasa asing. Hal ini menjadi perhatian khusus, karena ilustrasi seharusnya mempermudah siswa dalam me-

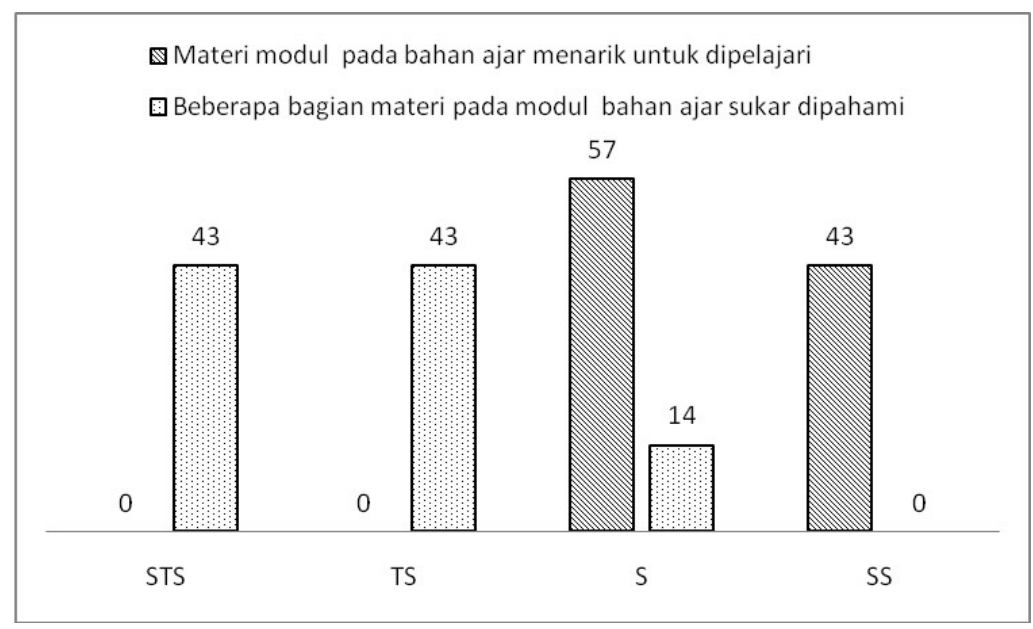

Keterangan: STS= sangat tidak setuju; TS= tidak setuju; $\mathrm{S}=$ setuju; $\mathrm{SS}=$ sangat setuju Gambar 1 Persentase Jawaban Responden dalam Menilai Prototipe Modul Bahan Ajar

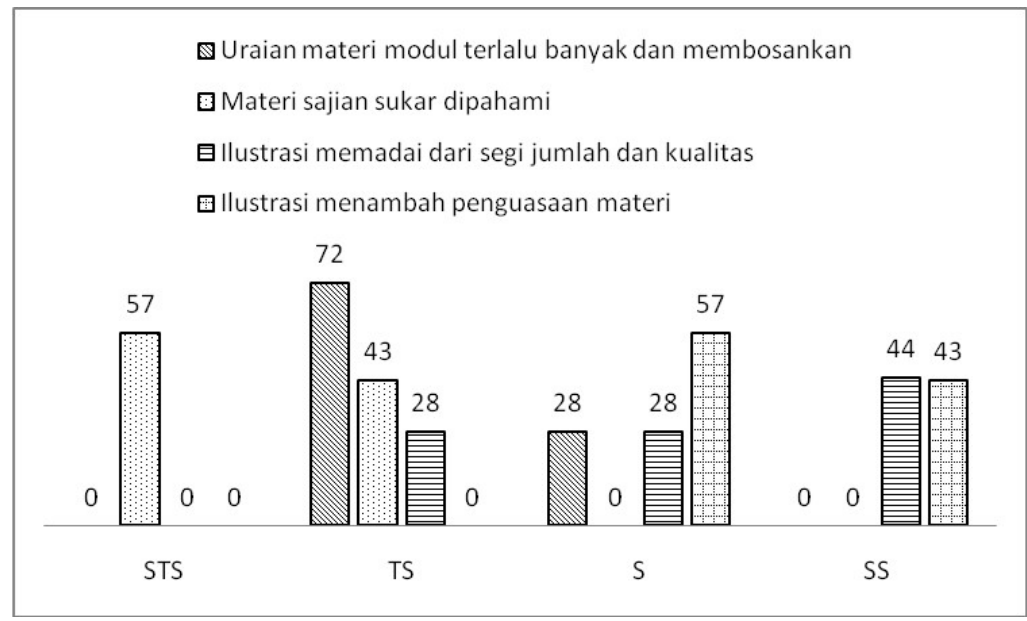

Keterangan: $\mathrm{STS}=$ sangat tidak setuju; $\mathrm{TS}=$ tidak setuju; $\mathrm{S}=$ setuju; $\mathrm{SS}=$ sangat setuju Gambar 2 Persentase Jawaban Responden terhadap Uraian Materi dan Ilustrasi Pototipe Bahan Ajar 
mahami materi tersebut. Hasil penelitian Mansourzadeh (2014) menguatkan bahwa penggunaan gambar dapat meningkatkan efektivitas dalam pembelajaran kosakata Iran EFL pada peserta didik tingkat pemula. Hal tersebut sejalan dengan hasil kajian literatur Stokes (2002) yang menyimpulkan bahwa penggunaan bahan visual dalam proses belajar mengajar menunjukkan hasil yang positif.

\section{Penilaian Responden terhadap Tugas, Latihan, Tes Formatif, Rangkuman, dan Glosarium}

Secara umum bagian akhir modul bahan ajar yang meliputi tugas, latihan, tes formatif, angkuman dan glosarium dinilai responden membantu pemahaman materi bahan ajar. Untuk lebih jelasnya dapat dilihat pada Gambar 3, tampak jelas bahwa sebagian besar responden menilai baik terhadap bagian akhir dari prototipe modul bahan ajar yang mencakup tugas, latihan, tes formatif, rangkuman, dan glosarium. Cakupan bagian akhir bahan ajar tersebut dianggap sesuai dengan materi sajian dan membantu penguasaan serta pemahaman materi. Namun, terdapat $<20 \%$ responden yang menyatakan bagian akhir dari modul bahan ajar tersebut tidak sesuai dengan materi dan kurang membantu dalam menguasai dan memahami materi.
Berdasarkan analisis terhadap penilaian langsung dengan cara membubuhkannya pada prototipe modul bahan ajar dapat dirangkum sebagai berikut. 1) Terdapat dua responden yang mengomentari adanya 4 gambar yang dianggap kurang jelas dan 2 gambar yang penjelasannya masih dalam bahasa asing; serta satu gambar yang ukurannya terlalu kecil. 2) Salah satu responden menganggap kalimat adanya penjelasan yang masih sulit dipahami.

\section{Hasil pre-test dan post-test}

Hasil pre-test dan post-test yang diolah secara deskriptif dengan menggunakan persentase responden yang menjawab benar dapat dilihat pada Tabel 1. Berdasarkan Tabel 1, materi prototipe modul bahan ajar Pendidikan Lingkungan Hidup tersebut yang perlu dikaji ulang adalah materi yang terkait dengan TIK nomor 1, 3, 10, dan 13. Hal ini perlu dilakukan karena setelah mempelajari prototipe modul bahan ajar tersebut, ternyata penguasaan responden terhadap materi yang diujikan terjadi penurunan. Padahal pre-test merupakan indikator dari penguasaan awal peserta didik terhadap materi (Ain, 2013; Jumiati dkk., 2011). Dengan demikian, dapat disimpulkan bahwa jika tidak terjadi peningkatan nilai post-test dibanding nilai pre-test apalagi jika lebih rendah, maka dapat diindikasikan bahwa peserta didik tidak mengerti apa yang dipelajarinya.

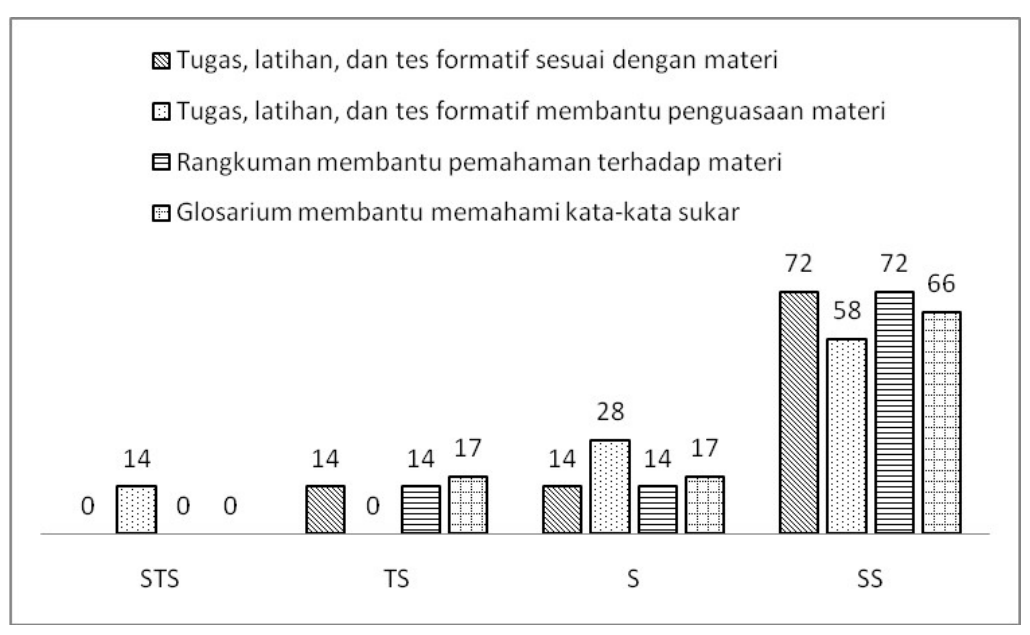

Keterangan: STS = sangat tidak setuju; TS = tidak setuju; $\mathrm{S}=$ setuju; $\mathrm{SS}=$ sangat setuju Gambar 3 Persentase Jawaban Responden Terhadap Penilaian Bagian Akhir Prototipe Bahan Ajar 
Tabel 1 Persentase Responden yang Menjawab Benar pada Pelaksanaan Pre-test dan Post-test Evaluasi Kelompok Kecil

\begin{tabular}{|c|c|c|c|}
\hline \multirow[t]{2}{*}{$\begin{array}{l}\text { No. } \\
\text { TIK/Soal }\end{array}$} & \multicolumn{2}{|c|}{$\begin{array}{l}\text { Persentase yang menjawab } \\
\text { dengan benar }\end{array}$} & \multirow[t]{2}{*}{ Keterangan } \\
\hline & Pre-test & Post-test & \\
\hline 1 & 44 & 13 & Materi perlu dilihat ulang \\
\hline 2 & 67 & 88 & Baik \\
\hline 3 & 33 & 25 & Materi perlu dilihat ulang \\
\hline 4 & 33 & 50 & Baik \\
\hline 5 & 67 & 100 & Baik \\
\hline 6 & 67 & 88 & Baik \\
\hline 7 & 44 & 75 & Baik \\
\hline 8 & 89 & 75 & Baik \\
\hline 9 & 33 & 50 & Baik \\
\hline 10 & 67 & 50 & Materi perlu dilihat ulang \\
\hline 11 & 22 & 63 & Baik \\
\hline 12 & 78 & 88 & Baik \\
\hline 13 & 100 & 88 & Materi perlu dilihat ulang \\
\hline 14 & 33 & 38 & Baik \\
\hline 15 & 44 & 63 & Baik \\
\hline
\end{tabular}

Tabel 2 Persentase Responden Yang Menjawab Benar Dalam Pelaksanaan Pre-test dan Post-test pada Tahap Uji Lapangan

\begin{tabular}{|c|c|c|c|c|}
\hline \multirow[t]{2}{*}{$\begin{array}{c}\text { No } \\
\text { TIK/Soal }\end{array}$} & \multicolumn{2}{|c|}{$\begin{array}{l}\text { Persentase menjawab } \\
\text { dengan benar }\end{array}$} & \multirow[t]{2}{*}{ Gain } & \multirow[t]{2}{*}{ Keterangan } \\
\hline & Pre-test & Post-test & & \\
\hline 1 & 64 & 77 & 13 & Baik \\
\hline 2 & 76 & 77 & 1 & Baik \\
\hline 3 & 43 & 77 & 34 & Baik \\
\hline 4 & 50 & 77 & 27 & Baik \\
\hline 5 & 43 & 69 & 26 & Baik \\
\hline 6 & 29 & 85 & 56 & Baik \\
\hline 7 & 68 & 69 & 1 & Baik \\
\hline 8 & 71 & 92 & 21 & Baik \\
\hline 9 & 21 & 62 & 41 & Baik \\
\hline 10 & 50 & 46 & -4 & Materi perlu dilihat ulang \\
\hline 11 & 71 & 85 & 14 & Baik \\
\hline 12 & 38 & 50 & 12 & Baik \\
\hline 13 & 100 & 88 & -12 & Materi perlu dilihat ulang \\
\hline 14 & 43 & 54 & 11 & Baik \\
\hline 15 & 21 & 31 & 10 & Baik \\
\hline
\end{tabular}




\section{Uji Coba Lapangan}

\section{Perbandingan Hasil Pre-test dan Post- test Setiap TIK}

Hasil analisis perbandingan antara nilai pre-test dengan nilai post-test dari responden dapat dilihat pada Tabel 2, maka prototipe modul bahan ajar ini masih perlu disempurnakan, terutama terkait TIK nomor 10 tentang prinsip pembangunan berwawasan lingkungan dan berkelanjutan dan TIK nomor 13 tentang prinsip daur ulang dalam pengelolaan sumber daya. Hal ini perlu dilakukan karena setelah mempelajari modul bahan ajar tersebut, ternyata penguasaanya terhadap materi yang diujikan terjadi penurunan. Jika kelemahan itu terjadi konsisten pada TIK yang sama baik pada evaluasi kelompok kecil dan uji lapangan, maka materi tersebut perlu dikaji ulang.

\section{Uji Beda nilai pre-test dan post-test}

Untuk menyakinkan bahwa terjadi perbedaan signifikan antara nilai pre-test dan post-test maka dilakukan uji t student berpasangan. Hasil uji-t tersebut dirangkum pada Tabel 3.

Karena signifikansi ( 2 tailed $)=0,001<0,05$, dapat disimpulkan bahwa terjadi perbedaan yang signifikan antara nilai pre-test dan posttest, di mana nilai pre-test secara signifikan lebih rendah dibanding nilai post-test. Hal ini menunjukkan bahwa prototipe modul bahan ajar dapat dipelajari dan dimengerti dalam waktu 2 jam, walaupun rata-rata pencapaian post-test baru $65,64 \%$ dengan gain rata-rata $(65,64$ -
$55,79=9,85 \%)$. Hal ini cukup memuaskan, karena untuk memahami materi satu modul bahan ajar jarak jauh seperti Universitas Terbuka, hingga capaian pemahamannya minimal $80 \%$ oleh peserta didik diperlukan waktu lebih kurang 15 jam (Suparman \& Zuhairi, 2004), padahal uji coba tersebut hanya dilakukan dalam waktu 2 jam saja.

\section{Persepsi Responden terhadap Bahan Ajar}

(1) Persepsi responden terhadap kemenarikan, kegunaan, dan kejelasan

Berdasarkan kuesioner yang diberikan dan dilakukan olah data secara dekriptif diperoleh hasil sebagai berikut.

Gambar 4 menunjukkan bahwa setelah melalui serangkaian uji coba dan revisi, hasil uji lapangan prototipe modul bahan ajar sudah cukup baik, dilihat dari segi kemenarikan, kegunaan, dan kejelasan dari segi kegunaan. Tidak ada satupun responden yang menyatakan bahwa materi modul bahan ajar kurang menarik, kurang berguna, atau kurang jelas. Hal ini menunjukkan bahwa prototipe modul bahan ajar yang dihasilkan sudah cukup memadai dari ketiga hal tersebut.

Hasil wawancara dengan salah satu responden terungkap bahwa: "Penjelasan pada setiap materi mudah dimengerti sehingga tes dapat dijawab sesuai dengan materi yang telah dibaca. Antara materi dengan tes yang diberikan berhubungan. Isi materi yaitu mengenai lingkungan (pelajaran IPA) menunjang profesi

Tabel 3 Rangkuman Hasil Uji t Berpasangan

\begin{tabular}{llrr}
\hline & & & \multicolumn{2}{c}{ Pair 1 } \\
& & & Pre-test - post-test \\
\hline & Mean & & $-9,857$ \\
Paired & Std. Deviation & & 8,986 \\
Differences & Std. Error Mean & & 2,402 \\
& 95\% Confidence & Lower & $-15,045$ \\
& Interval of the & Upper & $-4,669$ \\
$\mathrm{t}$ & Difference & & $-4,104$ \\
df & & & 13 \\
Sig. (2-tailed) & & & 0,001 \\
\hline
\end{tabular}

(Sumber: hasil olah data, menggunakan SPSS versi 20) 
saya sebagai guru sekolah dasar". Sementara itu, responden lainnya mengungkapkan bahwa: "Materi cukup menarik, dapat menambah wawasan, dan menjadi bahan masukan bagi guru. Bahasanya komunikatif, dan cocok digunakan oleh guru".

(2) Kejelasan materi yang disajikan

Berdasarkan hasil olah data kuesioner terkait kejelasan materi sajian diperoleh data seperti pada Gambar 5.

Pada Gambar 5 tampak jelas bahwa dari segi sajian, ternyata bahan ajar akhir ini sudah cukup memadai, karena sebagian besar responden mengatakan uraian materi bahan ajar tersebut sudah komunikatif, ilustrasinya menarik dan menggunakan istilah yang mudah dipahami. Walaupun demikian, bahan ajar tersebut masih perlu dilakukan sedikit perbaikan khususnya terkait peristilahan yang digunakan yang dikeluhkan oleh $31 \%$ responden. Selain itu, uraian materi perlu sedikit diperbaiki agar lebih komunikatif dan ilustrasi yang disajikan lebih menarik lagi walaupun hanya dinyatakan oleh masing-masing $8 \%$ responden.

Hasil wawancara dengan responden menunjukkan bahwa sebagian besar responden yang diwawancara mengungkapkan bahwa: "bahan ajar tersebut mudah dipahami, komunikatif, ilustrasi yang disajikan menambah pemahaman

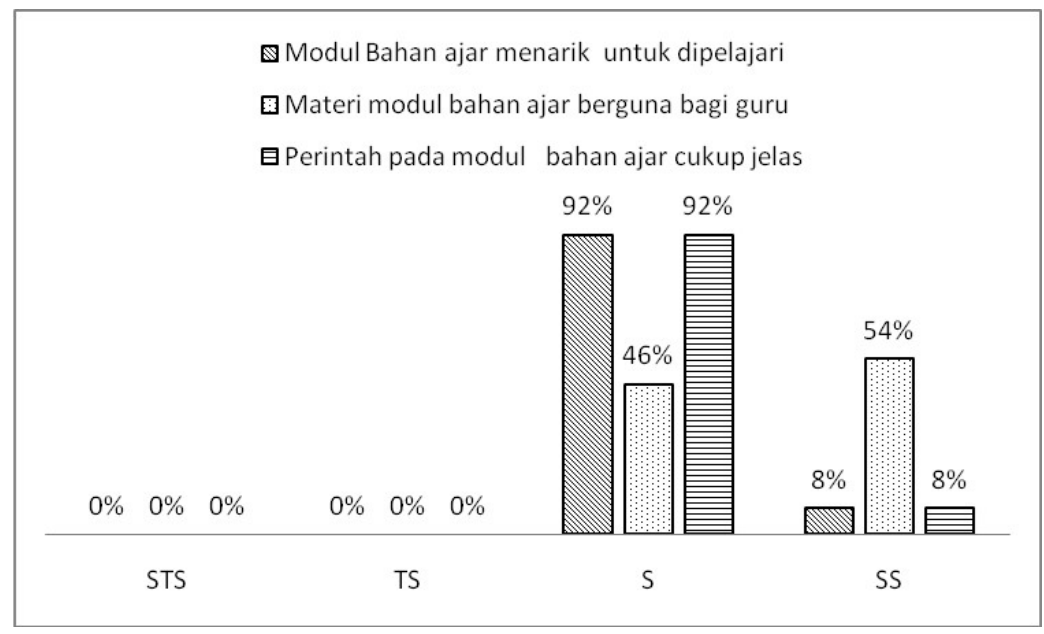

Keterangan: $\mathrm{STS}=$ angat tidak setuju; $\mathrm{TS}=$ tidak setuju; $\mathrm{S}=$ setuju dan $\mathrm{SS}=$ sangat setuju Gambar 4 Persepsi responden terhadap kegunaan, kemenarikan materi dan kejelasan perintah dalam bahan ajar

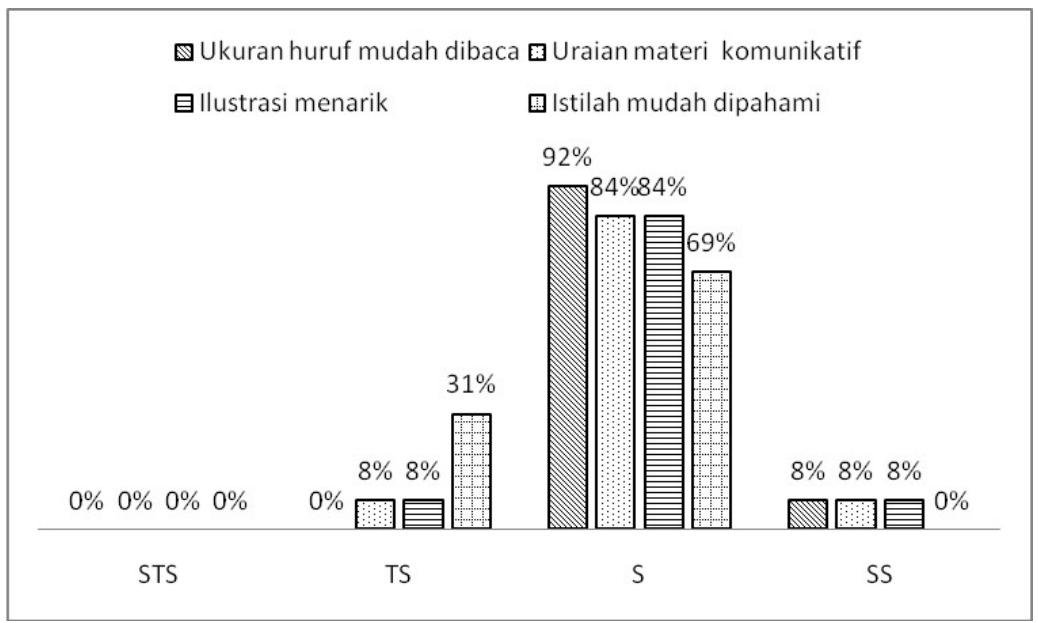

Gambar 5 Kejelasan Sajian Materi Prototipe Modul Bahan Ajar 
materi, dan huruf yang digunakan cukup mudah dibaca". Namun, di antara responden tersebut ada yang mengemukakan perlunya penjelasan istilah yang digunakan. Seperti yang dikemukakan salah satu dari responden: "Hendaknya tidak hanya kata-kata yang sulit dipahami yang diberi penjelasan, melainkan semua istilah perlu penjelasan, sehingga bahasan pada materi modul bahan ajar menjadi lengkap dan mudah dimengerti".

Dengan demikian jelaslah bahwa prototipe modul bahan ajar, setelah melalui serangkaian evaluasi dan revisi, secara umum telah menunjukkan peningkatan kualitas, yaitu menarik untuk dipelajari, mudah dipahami, komunikatif, dan berguna sebagai bekal untuk mengajar. Peningkatan kualitas merupakan tujuan utama dari evaluasi formatif, seperti tersirat dalam penelitian Farida dkk. (2013) bahwa evaluasi formatif yang digunakan dalam penelitiannya bertujuan untuk meningkatkan kualitas bahan ajar sehingga akan diperoleh bahan ajar yang lebih efektif. Kemudahan dan kemenarikan bahan ajar seperti diungkapkan oleh responden terjadi karena bahan ajar yang dikembangkan berguna bagi pebelajar. Hal ini sesuai dengan pendapat Harijanto (2007) bahwa "Agar bahan belajar dapat memudahkan pembelajaran, maka setiap bahan ajar harus memenuhi komponen-komponen yang relevan dengan kebutuhan pebelajar".

\section{SIMPULAN DAN SARAN}

\section{Simpulan}

Berdasarkan hasil dan pembahasan tersebut, dapat ditarik beberapa simpulan berikut. Pertama, hasil evaluasi satu-satu menunjukkan masih ada kelemahan pada prototipe modul bahan ajar, antara lain masih ada beberapa gambar yang kurang jelas dengan keterangan berbahasa asing, dan terdapat tes formatif yang tidak sesuai dengan materi serta beberapa istilah yang belum dijelaskan. Kedua, hasil evaluasi kelompok kecil, masih terlihat adanya hal-hal yang perlu diperbaiki, diantaranya masih ada responden yang menganggap materi terlalu banyak dan kurang menarik, ilustrasi gambar kurang memadai dari segi jumlah dan kualitas, serta bagian akhir dalam prototipe modul bahan ajar kurang sesuai dengan materi dan kurang membantu pemahaman materi. Hasil pre-test dan post-test menunjukkan materi mengenai pengertian dan sumber energi serta pengelolaan sumber daya alam masih perlu ditinjau kembali. Ketiga, hasil uji coba lapangan menunjukkan bahwa prototipe modul bahan ajar sudah cukup memadai dari segi kemudahan untuk dipelajari dan kegunaannya bagi mahasiswa, serta cukup menarik untuk dipelajari oleh mahasiswa. Namun istilah yang digunakan perlu dijelaskan lebih baik agar mudah dimengerti responden. Dengan demikian, tampak nyata bahwa melalui serangkaian ujicoba dan revisi, prototipe modul bahan ajar PLH menunjukkan peningkatan kualitas terutama dari sisi keterbacaan dan kegunaan bagi mahasiswa.

\section{Saran}

Dengan memperhatikan hasil penelitian ini yang menunjukkan masih cukup banyak masukan dari pengguna untuk menyempurnakan prototipe modul bahan ajar yang dikembangkan, walaupun secara konten telah direviu oleh pakar, maka disarankan: (1) Dalam pengembangan bahan ajar Universitas Terbuka sudah melakukan tahapan yang cukup baik, namun masih perlu melakukan uji coba bahan ajar yang telah direviu pakar kepada pebelajar melalui evaluasi formatif. (2) Bagi para pengembang bahan ajar dan penerbit, sebaiknya melakukan evaluasi formatif sebelum bahan ajar tersebut diterbitkan. (3) Bagi para peneliti, masih banyak tantangan untuk meneliti bahan ajar yang ada di lapangan, sehingga diperoleh bahan ajar yang memadai dan sesuai dengan kebutuhan pebelajar. 


\section{PUSTAKA ACUAN}

Ain, T.R. 2013. Pemanfaatan Visualisasi Video Percobaan Gravity Current untuk Meningkatkan Pemahaman Konsep Fisika pada Materi Tekanan Hidrostatis. Jurnal Inovasi Pendidikan Fisika. 2(2), 97-102.

Arlitasari, O., Pujayanto, \& Budiharti, R. 2013. Pengembangan Bahan Ajar IPA Terpadu Bebasis Salingtemas dengan Tema Biomassa Sumber Energi Alternatif Terbarukan. Jurnal Pendidikan Fisika. 1(1), 81-89.

Dick, W., Carey, L. \& Carey, J.O. 2001. The Systematic Design of Instructional ( $5^{\text {th }}$ ed). NewYork: Addison Wesley, Longman.

Dick, W., Carey, L. \& Carey, J.O. 2009. The Systematic Design of instructional (7 ${ }^{\text {th }}$ ed). London: Pearson Education Ltd.

Dunn K.E. \& Mulvenon S.W. 2009. A Critical Review of Research on Formative Assessment: The Limited Scientific Evidence of the Impact of Formative Assessment in Education. Practical Assessment, Research \& Evaluation. 14(7), 1-11.

Ediyanto. 2014. Pengembangan Model Penilaian Formatif Berbasis Web untuk Meningkatkan Pemahaman Konsep Fisika Siswa. Jurnal Pendidikan Sains. 2(2), 63-75.

Farida, I., Yani, D.E., \& Sigit, A. 2013. Analisis Kualitas dan Tingkat Keterbacaan Materi Bahan Ajar Cetak Melalui Evaluasi Formatif. Jurnal PTJJ. 14(2), 69-78.

Flagg, B. N. 1990. Formative Evaluation for Educational Technologies. Hillsdale, NJ: Lawrence Erlbaum Associates.

Harijanto, M. 2007. Pengembangan Bahan Ajar untuk Peningkatan Kualitas Pembelajaran Program Pendidikan Pembelajar Sekolah Dasar. Didaktika. 2(1), 216-226.

Hattie, J.A, Brown, G.T. L.,Ward, L., Irving, S.E, \& Keegan, P.J. 2006. Formative Evaluation of an Educational Assessment Technology Innovation: Developers' Insights into Assessment Tools for Teaching and Learning (asTTle). Journal of Multi Disciplinary Evaluation. Number 5. http://journals.sfu.ca/jmde/index.php/jmde 1/article/view File/50/57John. Diakses 27 Juli 2016

Jha, V. \& Duffy, S. 2002. Ten Golden Rules' for Designing Software in Medical Education: Results From a Formative Evaluation of Dialog. Medical Teacher. 24(4), 417-421.

Jumiati, Sari, M. \& Akmalia, D. 2011. Peningkatan Hasil Belajar Siswa dengan Menggunakan Numbereds Heads Together (NHT) pada Materi Gerak Tumbuhan di Kelas VIII SMP Sei Putih Kampar. Lectura. 2(2), 161-185.

Keller, J. M. 1987. The systematic process of motivational design. Performance and Instruction. 26(9), 1-8.

Mansourzadeh, N. 2014. A Comparative Study of Teaching Vocabulary through Pictures and Audio-visual Aids to Young Iranian EFL Learners. Journal of Elementary Education. 24(1), 47-59.

Ogle, G.J. 2002. Towards A Formative Evaluation Tool. Dissertation. Virginia Popytechnic Institute and State University. Virginia.

Pangesti, F. 2012. Pengembangan Bahan Ajar Pendidikan Berpikir (Kritis dan Kreatif) Berbahasa Indonesia SMA Melalui Pembelajaran Lintas Mata Pelajaran. e-Jurnal Universitas Negeri Malang. http://jurnal online. um.ac.id/data/artikel/artikel285. Diakses 20 Juli 2016. 
Maman Rumanta, Krisna Iryani, Anna Ratnaningsih, Pengembangan Modul Prototipe Bahan Ajar Cetak Mata Kuliah Pendidikan Lingkungan Hidup pada Pendidikan Terbuka dan Jarak Jauh

Pribadi, B.A \& Syarif, E. 2010. Pendekatan Konstruktivistik dan Pengembangan Bahan Ajar pada Sistem Pendidikan Jarak Jauh. Jurnal Pendidikan Terbuka dan Jarak Jauh. 11(2), 117-128.

Stewart, B.L. 2004. Formative and Summative Evaluation of Online Courses. The Quarterly Review of Distance Education. 5(2), 101-109.

Suartama, I.K. 2010. Pengembangan Multimedia untuk Meningkatkan Kualitas Pembelajaran pada Mata Kuliah Media Pembelajaran. Jurnal Pendidikan dan Pengajaran. 43(3), 253-262.

Stokes, S. 2002. Visual Literacy in Teaching and Learning: a Literature Perspective. Journal for the Integration of Technology in Education. 1(1), 10-19.

Sukerni, P. 2014 Pengembangan Buku Ajar Pendidikan IPA Kelas IV semester I SD no 4. Kaliuntu dengan Model Dick and Carey. Jurnal Pendidikan Indonesia. 3(1), 386-396.

Suparman, A \& Zuhairi A. 2004. Pendidikan Jarak Jauh: Teori dan Praktek. Jakarta: PAU-PPAI, Universitas Terbuka.

Suparman, A. 2014. Teknologi Pendidikan dalam Jarak jauh: Solusi untuk Kualitas dan Akisesibilitas Pendidikan. Tangerang Selatan: Universitas Terbuka.

Suswina, M. 2011. Hasil Validitas Pengembangan Bahan Ajar Bergambar Disertai Peta Konsep untuk Pembelajaran Biologi SMA Semester 1 Kelas XI. Ta'dib. 14 (1), 44-51.

Suwiwa, I.G, Santyasa, I.W, \& Kirna, I.M. 2014. Pengembangan Multimedia Interaktif Pembelajaran pada Mata Kuliah Teori dan Praktik Pencak Silat. e-Journal Program Pascasarjana Universitas Pendidikan Ganesha. (4). pasca.undiksha.ac.id/e-journal/ index.php/jurnal_tp/article/download/1372/1055. Diakses 25 Juli 2016

Triantafillou, E., Pomportsis, A., \& Demetriadis, S. 2003. The Design and The Formative Evaluation of an Adaptive Educational System Based on Cognitive Style. Computers and Education. 41, 87-103.

Yoshida, H. 2010. Development and Formative Evaluation of The "Educational Media Inservice Teacher Training Curriculum Standards". International Journal of Education and Development using Information and Communication Technology (IJEDICT). 6(3), 37-55.

Yuliana, E., Sadjati, I.M., \& Fadila, I. Penilaian Tingkat Keterbacaan Materi Modul Melalui Evaluasi Formatif. Jurnal Pendidikan Terbuka dan Jarak Jauh. 13(2), 113-124. 
Maman Rumanta, Krisna Iryani, Anna Ratnaningsih, Pengembangan Modul Prototipe Bahan Ajar Cetak Mata Kuliah Pendidikan Lingkungan Hidup pada Pendidikan Terbuka dan Jarak Jauh 